\title{
Idealitas Penguatan Kewenangan DPD RI dalam Perspektif Ketatanegaraan Indonesia yang Dinamis*
}

\author{
M. Muslih ${ }^{1}$ \\ Fakultas Hukum Universitas Batanghari Jambi, Indonesia \\ Correspondence email: muslih.ubr@gmail.com
}

\begin{abstract}
Abstrak. Dewan Perwakilan Daerah merupakan lembaga baru yang menggantikan Utusan Golongan dan Utusan Daerah sekaligus berfungsi sebagai anggota legislatif. Namun keberadaan DPD ini belum dimanfaatkan secara optimal dan tidak "disetarakan" dengan kedudukan DPR. Jika dilihat dari perspektif demokrasi dan kedaulatan rakyat proses keterpilihan anggota DPD sama dengan anggota DPR yakni melalui Pemilihan Umum Legislatif yang LUBER dan JURDIL. Oleh karena itu guna mengoptimalkan peran dan fungsinya, maka DPD perlu diperkuat kewenangannya dengan berbagai pemahaman dan arguimentasi yang mendukungnya.
\end{abstract}

Kata Kunci: Penguatan dan Kewenangan

Abstract. The Regional Representative Council is a new institution that replaces the Group and Regional Representatives as well as functions as a legislative member. However, the existence of this DPD has not been used optimally and is not "equalized" to the position of the DPR. When viewed from the perspective of democracy and popular sovereignty the electing process of DPD members is the same as that of DPR members through the LUBER and JURDIL Legislative Elections. Therefore, in order to optimize its role and function, the DPD needs to be strengthened with a variety of understandings and argumentations that support it.

Keywords: Strengthening and Authority

\section{PENDAHULUAN}

Sejarah mencatat bahwa semenjak kelahirannya, rancang bangun ketatanegaraan Indonesia didesain dan ditandai dengan adanya lembaga perwakilan guna mengakomodir kepentingan rakyat. Karena melalui lembaga perwakilan inilah maka berbagai kepentingan rakyat yang menyebar di berbagai wilayah dapat dikomunikasikan, atau tepatnya dapat dinegosiasikan dengan berbagai kebijakan nasional yang dirancang dan dijalankan oleh Negara dalam hal ini pemerintah. Selain itu lembaga perwakilan tersebut juga dapat melakukan pengawasan terhadap lembaga Negara lainnya terutama pemerintah (eksikutif). Di sisi lain Indonesia yang demikian luas wilayahnya dengan berbagai keberagaman komunitasnya tidak lepas dari pemikiran para pendiri Negara dalam memikirkan bentuk dan model perwakilan, sehingga menghasilkan model lembaga perwakilan yang khas Indonesia yakni Majelis Permusyawaratan Rakyat. Atas dasar pemikiran dan pertimbangan tersebut maka UUD 1945 yang disahkan oleh Panitia Persiapan Kemerdekaan Indonesia (PPKI) dengan mengakomodir keberadaan perwakilan daerah di Majelis Perusyawarata Rakyat dalam bentuk "utusan daerah" yang berdampingan/ bekerja sama dengan anggota Dewan Perwakilan Rakyat (DPR), dan utusan golongan dalam menjalankan tugas pokok dan fungsinya.

Menurut Harun Al Rasyid, sebagaimana dikutip oleh Reni Dwi Punomowati, bahwa latar belakang pembuat UUD menempatkan DPR sebagai wadah wakil-wakil partai politik hasil pemilu. Namun tidak semua orang masuk partai politik, sehingga DPR tidak dapat mewakili seluruh rakyat Indonesia, oleh karena itu maka diadakan badan yang lebih besar yakni MPR yang terdiri dari semua anggota DPR ditambah dengan wakil non parpol yang diwakili oleh Utusan Daerah dan Utusan Golongan ${ }^{2}$.

"Kekhasan Indonesia" atas Majelis Permusyawaratan Rakyat di atas oleh Jimly Ashiddiqie dapat dibandingkan dengan lembaga-lembaga Negara Indonesia yang lain yang dibentuk di awal kemerdekaan

\footnotetext{
*Makalah ini dipaparkan pada FGD yang diselenggarakan oleh MPR RI Tangal 25 September 2018 dengan Tema Penataan Kewenangan DPD

${ }^{1}$ Dosen Fakultas Hukum Univesitas Batanghari Jambi

${ }^{2}$ Reni Dwi Purnomowati, 2005, Implementasi Sistem Bikameral dalam Parlemen Indonesia, PT RajaGrafindo Persada, Jakarta, hal 2.
} 
lebih menyerupai "copy paste" dari lembaga Negara zaman Hindia Belanda, kecuali Majelis Permusyawaratan Rakyat (MPR) tidak ada contoh sebelumnya pada masa pemerintahan Hindia Belanda ${ }^{3}$.

Reformasi 1998, memberikan efek domino yang panjang terhadap berbagai dinamika sistem ketatanegaraan di Indonesia. Hal ini diawali dengan protes bebagai kalangan dimana mahasiswa manjadi penggerak di lapangan yang memaksa Presiden Suharto meletakkan jabatannya dan digantikan oleh Wakil Presiden BJ Habibi. Pada masa pemerintahan Presiden BJ Habibi inilah Pemilu yang seharusnya dilaksanakan pada Tahun 2002, dimajukan dan diselenggarakan pada Tahun 1999. Anggota MPR hasil pemilu 1999 inilah yang kemudian mengadakan perubahan atas UUD 1945, dimana kedudukan, struktur dan kewenangan MPR mengalami perubahan yang signifikan. Salah hasil perubahan tersebut adalah lahirnya lembaga-lembaga baru di Negara Indonesia, dimana salah satunya adalah Dewan Perwakilan Daerah sebagai diatur dalam Pasal 2, 22 C dan 22 D UUD 1945. Inti dari pengaturan ketiga pasal tersebut adalah bahwa anggota DPD otomatis juga sebagai anggota MPR, sedangkan dua pasal berikutnya mengatur bahwa anggota DPD merupakan wakil daerah yang jumlahnya sama setiap privinsi dan dipilih melalui proses pemilihan umum. Selain itu DPD memiliki fungsi legislasi, anggaran, pengawasan dan pertimbangan. Namun demikian fungsi tersebut di atas terbatas hanya pada tahap tertentu (mengajukan usulan RUU kepada DPR, ikut membahas rancangan RUU tanpa diberi hak/ kewenanangan untuk menyetujui atau menolak RUU tersebut dan dapat melakukan pengawasan atas pelaksanaan UU tertentu). Sementara itu kewenangan yang dibatasi di atas juga masih dibatasi pula pada bidang-bidang tertentu saja. Pembatasan berikutnya adalah bahwa hasil pengawasan dimaksud hanya dapat dilaporkan kepada DPR sebagai bahan pertimbangan untuk ditindaklanjuti, tapa memiliki hak untuk memanggil institusi yang malaksanakan UU yang diawasi tersebut, dalam hal ini pemerintah.

Mengingat kedudukan DPD sebagai lembaga perwakilan sekaligus sebagai anggota Majelis Permusyawaratan Rakyat yang demikian prestisius, akan tetapi jika dilihat dari aspek kewenangannya yang terbatas menjadi sangat ironis, hal inilah yang banyak disayangkan oleh berbagai fihak. Sehubungan dengan masalah tersebut maka banyak masukan dan saran agar pengaturan kewenangan Dewan Perwakilan Daerah disusun kembali sebagaimana mestinya. Dengan pengaturan kembali kewenangan DPD diharapkan akan mampu mendorong termanfaatkannya potensi yang besar yang ada di DPD guna membantu terlaksannya tujuan Negara dalam mewujudkan masyarakat makmur, sejahtera dan berkeadilan.

\section{Permasalahan}

Uraian di atas mendiskripsikan bahwa kewenangan Dewan Perwakilan Daerah sangat terbatas, akibatnya potensi yang dimilikinya kurang dapat dimanfaatkan secara optimal. Pertanyannya adalah bagaimana kewenangan ideal Dewan Perwakilan Daerah di masa yang akan datang?

\section{HASIL DAN PEMBAHASAN}

Kewenangan yang dimiliki DPD pada saat ini bersifat terbatas, keterbatasan kewenangan tersebut tentu tidak sesuai dan tidak berbanding lurus dengan tujuan semula membentuk DPD. Secara kelembagaan DPD merupakan sebuah parlemen (lembaga legislative) dimana MPR sebagai pembentuk dan pengubah UUD 45 menegaskan bahwa keberadaan DPD dalam struktur ketatanegaraan Indonesia dimaksudkan untuk (i) memperkuat ikatan daerah-daerah dalam wadah NKRI; (ii) meningkatkan agregasi dan akomodasi aspirasi dan kepentingan daerah-daerah dalam perumusan kebijakan nasional yang berkaitan dengan Negara dan daerah-daerah (iii) mendorong percepatan demokrasi pembangunan dan kemajuan daerah secara serasi dan seimbang ${ }^{4}$. Dengan demikian maka sudah selayaknya MPR merespon dan mengakomodir apa yang selama ini diperjuangkan oleh DPD untuk mendapatkan kewenangan yang layak dan seimbang dengan DPR. Penguatan di sini bukan dimaksudkan untuk bersaing dengan DPR, atau bahkan DPD harus mengalahkan atau lebih kuat dari DPR, penguatan di sini dimaksudkan untuk memposisikan keseimbangan yang wajar

3 Jimly Asshiddiqie, 2005, Format Kelembagaan Negara dan Pergeseran Kekuasaan dalam UUD 1945, UII PRESS, Yogyakarta, hal 37. selanjutnya Jimly menguraikan bahwa DPR dari volksraad, Presiden dari Gouvernuur General, Mahkamah Agung dari Landraad, Raad van Justitie dan Hogeraad di negeri Belanda, BPK dari Raad van Rekerkamer dan DPA dari Raad van Nederlandshce Indie, sedangkan MPR yang didudukkan sebagai lembaga negara tertinggi tidak ada padanannya pada zaman Hindia Belanda maupun di negeri Belanda, sedangkan MPR lebih “menyerupai”Majelis Rakyat Tertinggi (supreme people's council) yang digunakan oleh negara-negara dengan partai tunggal.

${ }^{4}$ Sirajuddin dan Winardi, 2015, Dasar-dasar Hukum Tata Negara Indonesia, Setara Press, Malang, hal 128 
antara DPD dan DPR sehingga dapat mewujudkan prinsip-prinsip check and balancis secara optimal. Konsep Check and balances (saling mengimbangi dan mengawasi) merupakan hasil pemikiran pencegahan dari asumsi bahwa kekuasaan yang tidak dibatasi cenderung akan disalahgunakan, dengan demikian kekuasaan tidak boleh berada di satu tangan. Pemikiran ini barangkali berbanding lurus atau mungkin terinspirasi tulisan John Locke pada tahun 1690 dengan judul second Treaties of Civil Government, yang intinya adalah bahwa kekuasan untuk menetapkan hukum tidak boleh dipegang sendiri oleh mereka yang menerapkannya. Prinsip pemikiran ini kemudian dikembangkan oleh Baron de Montesqueiu dengan konsep trias politica yang membagi kekuasaan Negara menjadi 3 yakni legislative, eksikutif dan yudikatif ${ }^{5}$.

Dalam hal ini MPR seakan-akan tidak konsisten terhadap konsep dan konstruksi yang ia bangun sejak awal kelahiran DPD. Hal ini tampak pada pemberian kewenangan DPD sebagaimana tetuang dalam Pasal 22D.

Dilihat dari perspektif wilayah sejatinya Indonesia ini semua terdiri dari daerah-daerah, wilayah pusat hanya merupakan semacam wilayah "imajiner" dari sebuah Negara, apalagi jika dilihat aspek wilayah, suku, tradisi, sumber daya alam dan sumber daya manusia dll. Karena sebelum ada Indonesia wilayah-wilayah daerah sudah ada. Dengan demikian mustinya MPR menyadari dan memahami hal tersebut dan tidak menutup mata akan realitas ini. Selanjutnya jika dilihat dari aspek tujuan pembangunan nasional, maka aktifitas pembangunan untuk mewujudkan masyarakat yang sejahtera, makmur dan berkeadilan ini juga banyak yang dilakukan di daerah. Dengan demikian sudah selayaknya jika DPD sebagai wakil daerah diberikan kewenangan yang selayaknya, tidak seperti yang tertuang dalam pasal 22D tersebut.

Sehubungan dengan uraian di atas maka diperlukan penataan kewenangan dalam bentuk penguatan kewenangan DPD. berkaitan dengan penataan kewenangan tersebut sejatinya sudah banyak masukan dan ide tentang bagaimana penguatan lembaga DPD dari berbagai ahli dan praktisi, oleh karena itu kemungkinan besar pemikiran penulis ini secara tidak langsung hanya akan mengulang ide-ide yang pernah dicetuskan, akan tetapi dalam konteks FGD ini penulis lebih menitik beratkan pada argumentasi mengapa penguatan tersebut layak dilakukan, dan kemungkinan implikasi yang akan muncul dan perlu disikapi.

\section{Kewenangan membentuk $U U$}

Titik sentral atau "ruh" dari lembaga legislative (parlemen) adalah kewenangan membentuk undangundang. Namun demikian DPD sebagai bagian dari parlemen oleh UUD 1945 diberikan kewenangan terbatas terutama dalam pembentukan undang-undang sebagaimana diatur dalam pasal 22D.

Penguatan terhadap lembaga DPD dalam membentuk UU ini dalam arti kewenangan sama sebagaimana dengan yang dimiliki oleh DPR. Jika dilihat dari "genetikanya" maka DPR dan DPD memang berbeda, DPR yang lahir dari "Rahim" Partai politik yang berorientasi pada kekuasaan, sedangkan DPD sebagai wakil daerah lahir dari kehendak, sekaligus berorientasi pada mempertahankan integrasi dengan upaya mewujudkan keseimbangan pembangunan antar daerah dan pusat serta pembangunan antara daerah yang satu dengan yang lain.

Kesetaraan kewenangan merupakan hal mendasar dan penting bagi sebuah institusi yang di dalamnya terdiri dari beberapa bagian, oleh karena itu memberikan kesempatan yang sama kepada kedua institusi (DPR dan DPD) dalam meperjuangkan kepentingan yang diwakilinya merupakan suatu keharusan. UUD 1945 hasil amandemen telah menetapkan parlemen kita dengan sistem bicameral. Asas kesamaan hukum yang dianut oleh UUD 1945 selain diberlakukan untuk setiap warga Negara mustinya juga dilakukan untuk lembaga-lembaga Negara dalam batas-batas kewajaran. Dilihat dari pendekatan sistem, apakah mungkin kenerja lembaga-lembaga legislative ini (DPR dan DPD) dapat optimal jika terjadi ketidak seimbangan dalam salah satu sub sistemnya. Karena jika salah satu sub sistem kurang optimal maka tujuan bersama alhasil akan sulit dicapai.

Namun demikian perlu difikirkan secara mendalam, jika DPD diberi kewenangan untuk membentuk undang-undang sebagaimana kewenangan DPR (walaupun hanya menyengkut bidang-bidang tertentu saja), maka pertama kali yang terbayang oleh kita adalah bahwa kewenangan membentuk UU adalah DPR, Presiden dan DPD. Skema seperti ini akan melahirkan 2 tantangan yang berat, pertama bahwa secara teknis untuk mendapatkan perstujuan dari DPR, DPD dan Presiden atau dengan kata lain untuk mendapatkan persetujuan dari 2 lembaga legislative dan eksikuti dalam hal ini presiden merupakan satu prosedur yang

\footnotetext{
${ }^{5}$ Jimly Asshiddiqie, 2010, Pengantar Ilmu Hukum Tata Negara, PT RajaGrafindo Persada, Jakarta, hal 285.
} 
sangat berat bahkan oleh Andrew S. Ellis dikatakan sebagai sesuatu yang mustahil ${ }^{6}$. kedua, kekacauan konstruksi berfikir, dimana MPR berwenang mengubah dan menetapkan UUD sebagaimana diatur pada pasal 37 ayat 1 UUD 1945, dengan kata lain jika kita memahami MPR dari perspektif pasal 2 UUD 1945, maka kewenangan mengubah dan menetapkan UUD ada di tangan DPR dan DPD.

Disisi lain UU yang jika dilihat dari aspek tata urutan perundang- undangan berada di bawah UUD bahkan UU dibentuk untuk melaksanakan perintah UUD, ironisnya lembaga yang membentuk UU (sebagai pelaksanan dari perintah UUD) justru lebih besar dan lebih sulit untuk membentuk dan menghasilkan persetujuan, karena melibatkan DPR, DPD dan Presiden.

Dilihat dari perspektif konsistensi dan tata urutan perundang-undangan realitas seperti ini tentu tidak baik dan akan menimbulkan kekacauan konstruksi berfikir secara logis dan konsisten.

Sehubungan dengan hal tersebut maka perlu dilakukan beberapa hal sebagai berikut:

a. Kewenangan presiden membentuk UU hendaknya dicabut. Pemikiran ini didasarkan pada pendapat John Locke pada tahun 1690 dengan judul second Treaties of Civil Government, yang intinya adalah bahwa kekuasan untuk menetapkan hukum tidak boleh dipegang sendiri oleh mereka yang menerapkannya. Sehubungan dengan pencabutan kewenangan tersebut otomatis dimunculkan penyeimbang antara lembaga legislative dan eksikuti berupa kewenangan menerima atau menolak setiap UU yang disusun oleh lembaga legislatif.

b. Pasal 20 (1) mengatur bahwa DPR memegang kekuasaan membentuk UU, artinya bahwa pemegang kekuasaan mebentuk UU di Indonesia adalah legislative. Secara historis amandemen UUD 1945 ini dimaksudkan untuk mengkoreksi hal-hal yang dirasakan kurang tepat pada masa rezim sebelumnya, bahkan dalam konteks pembentukan UU DPR sering disebut sebagai "tukang stempel" pada saat itu. Dengan demikian maka sejatinya pasal 20 (1) yang berisi pengalihan fungsi legislative dari Presiden ke DPR itu secara teoritis dapat dimaknai sebagai penerimaan secara tidak langsung terhadap prinsip pemisahan kekuasaan (separation of power), dimana selama UUD 45 sebelum diamandemen cenderung mengakomodir prinsip (devision of power) pembagian kekuasaan. Jika memang DPD ingin dibekali dengan kewenangan ikut membentuk UU, maka sejatinya pintu masuknya secara tidak langsung telah dibuka. Konsekwensi logis yang harus dimunculkan adalah bagaimana menetapkan kewenangan DPD dalam hal pembuatan UU ini diberi kepastian hokum, oleh kmarena itu penulis setujua dengan beberapausulan bahwa pasal 20 UUD 1945 perlu ditambahkan ayat yang intinya menegaskan bahwa DPD bersama DPR membentuk UU.

Sehubungan dengan hal tersebut tentu akan diikuti berbagai perubahan format keadministrasian misalnya tentang kop kertas yang memuat UU, frasa awal, yang mengasahkan, yang mengudangkan dll.

c. Salah satu tujuan dilakukannya amandemen terhadap UUD 1945 adalah ingin memurnikan sistem pemerintahan presidensial. Terhadap tujuan ini UUD 1945 hasil amandemen sudah mengakomodir cara dan teknis pemilihan Presiden, dari dipilih oleh MPR (parlemen) menjadi dipilih langsung oleh rakyat, demikian juga tentang kepada siapa presiden bertanggungjawab. Indikator presidensial bukan hanya masalah pemilihan presiden tetapi juga dapat dikaitkan dengan masalah pembentukan UU. Oleh karena itu menjadi sesuatu yang dimungkinkan untuk menempatkan DPD sebagai pembentuk UU dan menarik Presiden dari kewenangan membentuk UU.

d. Proses pemilihan anggota DPD sama dengan proses pemilihan DPR, yakni sama-sama dipilih langsung oleh rakyat melalui pemilihan umum. Bahkan jika dilihat dari aspek legitimitas maka secara umum anggota DPD lebih banyak dipilih oleh rakyat dibandingkan dengan anggota DPR. Hal ini terjadi karena alasan sebagai berikut:

(i) Anggota DPD menggunakan sistem distrik berwakil banyak dengan distrik tingkat provinsi, oleh karena itu calon anggota DPD yang terpilih rata-rata didukung jumlah suara yang lebih banyak dari calon anggota DPR terpilih. Setiap Provinsi hanya 4 orang yang terpilih dengan daerah pemilihan provinsi. Sedangkan daerah pemilihan untuk DPR adalah provinsi atau bagian dari provinsi, dengan jumlah calon anggota DPR yang jauh lebih banyak. Sementara itu jumlah olemilihnya sama yakni yang terdaftar dalam DPT.

${ }^{6}$ Andrew S. Ellis, Lembaga Legislatif Bikameral, sebuah Agenda dan beberapa Pertanyaan, Makalah dipresentasikan pada Seminar Bikameralisme dan Perubahan Konstitusi di Jakarta, 8 Juni 2001. 
Situasi ini menyebabkan perbedaan persebaran jumlah pemilih yang tidak seimbang antara subjek yang dipilih antara calon anggota DPR dan calon anggota DPD. Sehubungan dengan hal tersebut maka secara matematis anggota DPD yang terpilih memiliki potensi lebih banyak mendapat dukungan suara secara langsung dari rakyat. Sedangkan anggota DPR dukungannya didapat dari pemilih yang memilih ddsi calon tersebut secara langsung, dari pemilih yang memilih caloi lain dalam satu partai yang tidak terpilih dan dari pemilih yang memilih gambar partai politik peserta pemilu.

(ii) Tingkat distorsi pilihan lebih kecil. Anggota DPD yang terpilih jauh lebih legitimate dibandingkan dengan anggota DPR terpilih. Hal ini tejadi karena calon anggota DPD dipilih secara personal, artinya setiap suara yang masuk memang diperuntukkan kepada pribadi calon anggota DPD dengan menggunakan mekanisme memilih/mencoblos gambar calon anggota. Selanjutnya dalam penghitungan untuk menentukan calon terpilih maka calon anggota DPD dihitung berdasarkan ranking yakni terbanyak $1 \mathrm{~s} / \mathrm{d}$ terbayak 4 . Sedangkan calon anggota DPR yang terpilih mewakili dirinya sendiri, mewakili suara temannya yang diakomodir melalui partai politik, dan suara yang hanya diperuntukkan kepada partai politik. Penghitungan dan penentuan calon terpilih melalui gabungan suara pribadi maupun suara partai politik dari suara setiap calon anggota dan suara untuk partai. Bahkan dari aspek teknis memilih, maka Hal ini berberbeda dengan anggota DPR dengan demikian ada kemungkinan terjadinya distorsi antara pilihan pemilih dengan calon anggota terpilih.

\section{DPD dilibatkan dalam memberikan persetujuan terkait dengan Hak Prerogratif Presiden Hak Prerogatif}

Secara historis hak prerogative berawal di Inggris, ia merupakan hak istimewa bagi penguasa politik untuk memutuskan sesuatu berdasarkan pertimbangan sendiri, putusan tersebut dapat dilakukan tanpa alasan apapun kecuali KEHENDAK PRIBADI SANG PEMIMPIN. Selanjutnya dalam pemerinmtahan modern saat ini hak prerogtaif dimaknai sebagai Hak yang dimiliki oleh kepala Negara/ pemerintahan dalam bidangbidang tertentu yang dinyatakan dalam konstitusi. ${ }^{7}$

a. Pasal 11 UUD NRI Tahun 1945 pada intinya mengatur bahwa (1) Presiden dalam menyatakan perang, membuat perdamaian dan perjanjian dengan negara lain yang menimbulkan akibat yang luas dan mendasar bagi kehidupan rakyat, harus dengan persetujuan Dewan Perwakilan Rakyat.

Sebagai Negara yang sangat luas dan mayoritas penduduknya tersebar di berbagai daerah, maka ketika Presiden akan menetukan perang atau akan mengadakan perdamaian dengan suatu negara, maka yang paling terdampak adalah rakyat. karena pada akhirnya resiko baik perang maupun damai akan menanggung adalah rakyat, apalagi jika dilihat bahwa pertahanan dan mempertahankan kedaulatan juga menjadi kewajiban setiap warga negara. Oleh karena itu wakil rakyat (DPR) dan wakil daerah (DPD) juga harus dilibatkan dalam pengambilan putusan tersebut. Begitu juga ketika Presiden mengadakan perjanjian dengan suatu negara tentu dampak dan keberlakukan perjanjian dengan negara lain tersebut juga akan mengikat setiap warga negara di seluruh wilayah Indonesia.

Selanjutnya bahwa perang, perdamaian dan perjanjian harus dikemas dalam dokumen resmi (UU), oleh karena itu sebagai konsekwensi dari usulan bahwa DPD juga dilibatkan secara setara dalam menyusun UU maka otomatis DPD dilibatkan dalam memberi pertimbangan kepada presiden dalam menjalankan hak prerogative yang diatur dalam Pasal 11 UUD 1945.

b. Pasal 24 ayat (2) UUD 1945 mengatur bahwa Mahkamah Konstitusi wajib memberikan putusan atas pendapat Dewan Perwakilan Rakyat mengenai dugaan pelanggaran oleh Presiden dan/atau Wakil Presiden menurut Undang-Undang Dasar. DPD selayaknya juga dilibatkan ketika dalam memberikan pendapat apakah presiden telah melakukan pelanggaran konstitusi atau tindak pidana lainnya.

Ada beberapa argumentasi logis atas usulan di atas antara lain:

(i) bahwa baik DPR maupun DPD sama-sama dipilih oleh rakyat, bahkan secara detail jika dilihat dari prespektif legitimitas DPD berpotensi lebih legitimate sebagaimana telah penulis jelaskan sebelumnya.

\footnotetext{
${ }^{7}$ https://seputarpengertian.blogspot.com/2016/06/pengertian-hak-prerogatif.html
} 
(ii) Presiden bukan hanya presidennya rakyat yang tergabung dalam partai politik yang diwakili oleh DPR, Presiden juga presidennya orang-orang yang tidak masuk dalam partai politik yang konsep awalnya diwakili oleh utusan daerah dan dan utusan golongan yang kemudian diubah menjadi DPD.

Hal ini dapat dilihat bahwa jumlah pemilih tidak sama dengan jumlah penduduk Indonesia, sebagai contoh jumlah penduduk Indonesia Tahun 2014 sebanyak 253.609 .643 jiwa. ${ }^{8}$ dan jumlah pemilih dalam Daftar Pemilih Tetap pada Pemilu 2014 sebanyak 188.268.423 jiwa9 , dengan demikian terdapat selisih sebanyak 65.341.220 jiwa $^{10}$. Angka ini setara dengan $25,76 \%$

(iii) Syarat kemenangan presiden sebagaimana diatur dalam pasal 6A ayat (3) UUD 45, selain memperoleh lebih dari 50\% masih terdapat syarat tambahan yakni harus memperoleh suara minimal $20 \%$ suara disetiap provinsi yang tersebar lebih dari setengah jumlah provinsi. Artinya bahwa untuk memenangkan kontestasi presiden wilayah/ daerah dijadikan sebagai syarat kemenangan, dengan demikian maka wakil-wakil daerah sebagai "pemilik" wilayah layak dimintai pertimbangan dan persetujuannya terhadap kebijakan presiden yang berdampak pada rakyat banyak yang mayoritas berada di daerah.

\section{Penambahan jumlah anggota DPD}

Guna memperkuat kedudukan dan posisi tawar DPD dalam pelaksanaan tugas pokok dan fungsinya yang berkaitan dengan check and balances, selain kewenangan yang harus ditingkatkan, maka jumlah personilnyapun juga harus seimbang. Alasan perlunya penambahan jumlah personil/ anggota DPD antara lain:

a. Hal ini penting untuk dapat mewujudkan prinsip check and balances, meskipun sila 4 Pancasila mengajarkan musyawarah mufakat, akan tetapi fenomena saat ini orang cenderung bersikap pragmatisme, tidak sabar mendengar argumentasi, barangkali malas berfikir keras, ego sentral yang terlalu dominan sehingga segala permasalahan yang sulit disepakati cenderung diselesaikan dengan voting. Pada situasi seperti inilah (voting) maka ukuran kuantitas atau jumlah anggota menjadi sangat penting.

b. Wilayah Indonesia sangat luas, pembatasan anggota DPD tidak boleh lebih dari 1/3 jumlah MPR sebagaimana diatur dalam pasal 22C ayat (2) ini merupakan konstruksi hukum yang perlu difikirkan kembali. Berangkat dari kecenderungan voting dalam proses demokrasi kita, pembatasan jumlah anggota DPD di atas merupakan desain seakan-akan justru untuk dilemahkan. Bagaimana mungkin aspirasi yang diperjuangkan oleh DPD akan dapat dikaji pada tingkat lanjutan kalau setiap usulan awalnya selalu dengan mudah dapat dipatahkan, hanya karena kalah voting (mati pucuk). Konstruksi hukum yang demikian ini merupakan gambaran apa yang dikemukakan oleh Prof. Satjipto Rahardjo, bahwa arsitek kegagalan hukum dimulai sejak pembuatannya.

Meminjam ukuran/ indikator dari Chambliss dan Seidmann ${ }^{11}$ tentang model masyarakat, penulis berpendapat bahwa masyarakat Indonesia sudah memenuhi kriteria sebagai model masyarakat konflik, dimana masyarakat yang satu cerderung tidak sama kepentingannya dan bahkan tidak sekedar berbeda melainkan bertentangan. Sehingga dalam pebuatan hukumnyapun (UUD 45 dalam merumuskan kewenangan DPD) pilih memilih kepentingan tidak dapat dielakkan. Oleh karena itu ketika merumuskan dan menetapkan keberadaan DPD yang bersifat kelembagan diperlakukan dan diproses seperti mengatur kepentingan individu masing-masing anggota DPD. Padahal keberadaan DPD ini sejatinya untuk kepentingan parlemen, yang pada giliranya untuk kepentingan seluruh bangsa Indonesia. Maka sangat tidak bijak kalau masalah kelembagaan ini kemudian dipolitisasi seakan-akan menjadi urusan individu ataupun kelompok.

\footnotetext{
${ }^{8}$ https://salin8er8agiituindah.blogspot.com/2014/11/jumlah-penduduk-indonesia-tahun-2014.html

${ }^{9} \mathrm{http}$ ://kota-cirebon.kpu.go.id/berita/kpu-tetapkan-dpt-pilpres-2014-secara-nasional

${ }^{10}$ Jumlah warga Negara yang tidak masuk dalam DPT ini tersebar ke dalam beberapa klasifikasi, pertama mereka adalah orang yang oleh UU memang tidak diberi hak pilih (seperti TNI dan POLRI) berdasarkan Putusan Mahkamah Konstitusi atas Perkara Nomor 22/PUU-XII/2014. (https://nasional.kompas.com/read/2014/05/28/1226045/MK.Anggota.TNI-Polri. Tak.Punya. Hak.Pilih. dalam. Pilpres.). dan mereka yang belum mencapai umur 17 Tahun.
}

11 Satjipto Rahardjo, 1980, Hukum dan Masyarakat, Angkasa, Bandung, hal 49. 
c. Fokus pembangunan nasional justru terletak di daerah.

Pada prinsipnya mayoritas masyarakat kita berada di daerah, sehingga pemerintah menetapkan kebijakan otonomi daerah sebagai koreksi terhadap kebijakan pembangunan sebelumnya yang bersifat sentralistik. Otonomi daerah bertujuan untuk melancarkan roda pembangunan di daerah yang pada gilirannya untuk meningkatkan kesejahteraan masyarakat sebagai perwujudan tujuan nasional. Sehubungan dengan hal tersebut maka semakin banyak jumlah anggota DPD dimungkinkan aspirasi dan aksesbilitas kepentingan daerah untuk menjadi program nasional menjadi lebih kuat, dengan demikian maka perwujudan tujuan nasional akan lebih cepat diwujudkan.

\section{KESIMPULAN}

Demikian beberapa usulan penguatan kewenangan dalam rangka penataan kewenangan DPD, yakni agar DPD diberi kewenangan untuk iku membentuk UU secara penuh (apakah bidang tertentu saja atau seluruh bidang dapat didiskusikan lebih lanjut). Usulan di atas tentu akan berimplikasi terhadap beberapa hal yang tersebar di beberapa pasal dalam UUD 1945, dan tidak dibahas dalam tulisan ini.

Berbicara tentang penguatan kewenangan DPD berarti membicarakan perubahan UUD 1945 sebagai konstitusi. Prof Mahfud MD menegaskan bahwa berkonstitusi itu bukan harus mengikuti teori-teori, atau harus mencontoh dari negara lain yang telah maju, melainkan tergantung bagaimana kesepakan kita tentang apa dan bagaimana pengaturan prinsip-prinsip dasar bernegara itu yang didasarkan pada situasi dan kondisi yang ada. Karena keadaan suatu negara dengan segala kondisinya tidak sama di setiap negara.

\section{DAFTAR PUSTAKA}

Jimly Asshiddiqie, 2005, Format Kelembagaan Negara dan Pergeseran Kekuasaan dalam UUD 1945, UII PRESS, Yogyakarta. , 2010, Pengantar Ilmu Hukum Tata Negara, PT RajaGrafindo Persada,

Reni Dwi Purnomowati, 2005, Implementasi Sistem Bikameral dalam Parlemen Indonesia, PT RajaGrafindo Persada, Jakarta.

Satjipto Rahardjo, 1980, Hukum dan Masyarakat, Angkasa, Bandung Sirajuddin dan Winardi, 2015, Dasar-dasar Hukum Tata Negara Indonesia, Setara Press, Malang. Andrew S. Ellis, Lembaga Legislatif Bikameral, sebuah Agenda dan beberapa pertanyaan, Makalah. UUD Negara Kesatuaan Republik Indonesia Tahun 1945.

https://seputarpengertian.blogspot.com/2016/06/pengertian-hak-prerogatif.html https://salin8er8agiituindah.blogspot.com/2014/11/jumlah-penduduk-indonesia-tahun-2014.html http://kota-cirebon.kpu.go.id/berita/kpu-tetapkan-dpt-pilpres-2014-secara-nasional https://nasional.kompas.com/read/2014/05/28/1226045/MK.Anggota.TNI-Polri.Tak.Punya.Hak.Pilih. dalam.Pilpres. 